\title{
In vitro fermentation and chemical constituents of urea-molass es feed - blocks made with different bind ers for ruminants.
}

\author{
O. A. Isah
}

Department of Animal Nutrition, Federal University of Agriculture, Abeokuta, Nigeria.

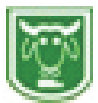

E-mail: bukkyisah@yahoo.com

\begin{abstract}
This study was carried out to as sess the chemical contents, in vitro break down, volatile fatty acids, $N H 3 \neg-N$ and methane concentration of urea-molasses feed - block (UMFB) using different binders. Four feed - blocks were formulated as: UMFB A (Cement only), UMFB B (cement + clay), UMFB C (cement + cassava starch), and UMFB D (cassava starch + clay). The feed-blocks were incubated in vitro for 48 hours to assess gas production and other in vitro- ecology parameters. Results of chemical analysis revealed that UMFB C (21.70\%), and B (21.65\%) had highest $(p<0.05)$ crude protein content while UMFB D (18.62\%) had lowest value. Intermediate crude protein content was recorded for UMFB A (19.58\%). However, highest $(p<0.05)$ values of $A D F(16.8 \%)$ and $A D L$ (15.5\%) were recorded for UMFB D. Similar value of $A D F(16.70 \%)$ and $A D L(15.3 \%)$ were recorded also for UMFB B. The NDF value of feed - block $A(34.6 \%)$ was highest $(p<0.05)$ while lowest value of NDF was recorded for UMFB D (32.1\%). Production of volatile fatty acids indicated that propionic acid (30.5\%), oleic acid (11.3\%) and lactic acid $(36.5 \%)$ were highest $(p<0.05)$ for $U M F B$ D. Concentration of $\mathrm{NH}_{3}-\mathrm{N}$ was highest in $U M F B$ B while significant difference $(p>0.05)$ was not observed in the $p H$ and methane values for various UMFB. Highest in vitro digestibility of organic matter was observed in UMFB D. The study showed that the various feed-blocks could serve as a sustainable supplement during dry season and period of scarcity for the ruminants.
\end{abstract}

Keywords: In vitro degradation, urea- molasses feed - block

\section{Introduction}

One of the major constraints to increasing livestock productivity in developing countries is the scarcity and fluctuation in quantity and quality of the year-round supply of conventional ruminant feeds. With increase in demand for livestock products as a result of rapid growth in the world human population, expanding economies and shrinking land area, future hopes of feeding the millions of people and safeguarding their food security will depend on the better utilization of feed resources, which cannot be used as food for humans. Urea-molasses multi-nutrient blocks (UMFB) have been found to be highly beneficial and its use has been shown to be practical and effective in overcoming nutritional challenges in sheep, goats, beef and dairy cattle industry (Makkar, 2006). The in-vitro gas production method is an accurate and reliable tool for the evaluation of fermentation potentials of feeds and it predicts feed intake, digestibility, microbial nitrogen supply and animal performance (Blümmel and Ørskov, 1993). It is less expensive and less time-consuming. The invitro fermentation technique is capable of quantifying the amount of methane (energy loss) production (Fievez et al., 2005), and determine the amount of acetate, propionate and butyrate (Babayemi et al,. 2004), carbon dioxide and metabolizable energy of feed for ruminants (Blümmel et al., 1997). The objective of this study therefore is to assess the in vitro and chemical composition of urea-molasses 
feed - blocks as feed for ruminants.

\section{Materials and Methods}

Preparation of Urea Molasses Feed Block

Locally available feed ingredients and agro-industrial by-products were sourced from commercial feed - miller in Abeokuta, Ogun State, which is located in the tropical rainforest zone in Nigeria within $7^{\circ} 10 \mathrm{~N}$ and $3^{0} 2^{\prime} \mathrm{E}$. The area has an average rainfall of $1100 \mathrm{~mm}$, a mean ambient temperature of about $34^{\circ} \mathrm{C}$ and an average relative humidity of $82 \%$. Four feed - blocks were formulated (Table 1) as: UMFB A (Cement only), UMFB B (cement + clay), UMFB C (cement + cassava starch), and UMFB D (cassava starch + clay). Production of feed blocks was done using a "cold process" as described by Brar et al., (2006) but modified for local production (Table I). Urea and molasses were mixed together and left for 24 hours. Common - salt was mixed with corn - cob before mixing with other dry ingredients, to give uniform distribution of the premix. The urea-molasses mixture was poured into the premix of the dry ingredients, prepared on a big plastic bowl of 50 litre capacity, and mixed thoroughly. One kg of the semi-solid mixture was then put in small plastic cases $(12.5 \times 10 \times$ $5.5 \mathrm{~cm}$ ), covered with a wooden sheet (that fitted well into the case) and compressed within two minutes. The plastic case was later pulled out leaving the formed UMFB on the polythene sheet. The UMFBs were left at room temperature for one week to dry so as to be hard enough for handling, transportation and feeding.

In vitro degradation analysis of the ureamolasses feed - block

Inoculum was obtained through sunction tube from fistulated West African dwarf (WAD) rams before morning feeding. The animals were previously fed with a mixed diet of fresh Pennisetum purpureum (60\% $\mathrm{DM})$ and concentrates (40\% DM). The concentrate feed consisted of (as fed basis) $4 \%$ corn, $10 \%$ wheat offal, $10 \%$ palm kernel cake, $20 \%$ groundnut cake, $5 \%$ soyabean meal, $10 \%$ dried brewers' grain, $1 \%$ common - salt, $3.75 \%$ oyster shell and $0.25 \%$ fish - meal (Babayemi and Bamikole, 2009). The fluid was strained through four layers of cheese cloth into a pre-warmed, insulated bottle. All laboratory handling of rumen fluid was carried out under a continuous flow of $\mathrm{CO}_{2}$. The incubation procedure was as reported by Menke and Steingass, (1988). The gas

Table 1: Ingredient composition of u rea-molasses feed - blocks

\begin{tabular}{lllll}
\hline Ingredients (\%) & \multicolumn{5}{l}{ Feed-block Treatments } & $\mathrm{C}$ & $\mathrm{D}$ \\
\cline { 2 - 5 } & $\mathrm{A}$ & $\mathrm{B}$ & 35 & 35 \\
Molasses & 35 & 35 & 10 & 10 \\
Urea & 10 & 10 & - & 5 \\
Clay & - & 5 & 5 & - \\
Cement & 10 & 5 & 5 & 5 \\
Cassava starch & - & - & 5 & 5 \\
GNC & 5 & 5 & 20 & 20 \\
Wheat offal & 20 & 20 & 10 & 10 \\
Corn cob & 10 & 10 & 8 & 8 \\
Rice Bran & 8 & 8 & 1.5 & 1.5 \\
Common Salt & 1.5 & 1.5 & 0.5 & 0.5 \\
Vit/Min Premix & 0.5 & 0.5 & & \\
\hline UMFB A (Cement only), UMFB B (cement + clay), UMFB C (cement + cassava starch), and UMFB \\
D (cassava starch + clay).
\end{tabular}


production was measured on the calibration of the syringe for 48 hour.

\section{Chemical analysis}

Known weight of the UMFB from each feed - blocks was sampled air drying. The samples were oven-dried to constant weight at $65^{\circ} \mathrm{C}$. The dried samples were hammer-milled through a $1 \mathrm{~mm}$ sieve. Crude protein (CP), crude fibre (CF), ether extract (EE) and ash contents of samples were carried out in triplicates as described by AOAC (1990). The amount of CP was calculated $(\mathrm{N} \times 6.25)$. The neutral detergent fibre (NDF), acid detergent fibre (ADF) and acid detergent lignin (ADL) were determined according to Van Soest et al (1991). The $\mathrm{pH}$ was measured using a $\mathrm{pH}$ meter (pH meter : CT-6020 Kedid waterproof $\mathrm{pH}$ meter XB858 SN: 85886948). The $\mathrm{NH}_{3}-\mathrm{N}$ concentration was measured by spectrophotometry according to Chaney and Marbach (1962). The analysis of volatile fatty acids (VFA) concentration was carried out using Gas Liquid Chromatography (Samuel et al., 1997). The molar percentages of propionic, acetic, lactic, butyric acid and oleic acids were determined. The volume of methane gas produced by each sample was determined by addition of $4 \mathrm{ml}$ of $10 \mathrm{~N}$ sodium hydroxide (Fievez et al., 2005).

\section{Statistical analysis}

In vitro Organic matter digestibility (IVOMD\%) was assessed as IVOMD
$=14.88+0.889 \mathrm{GV}+0.45 \mathrm{CP}+0.651 \mathrm{XA}$ according to Menke and Steingass, (1988). Data obtained were subjected to analysis of variance at $\mathrm{p}=0.05$. Where significant differences occurred, the means were separated using Duncan's multiple range test of the SAS, (1990) options.

\section{Results}

Chemical composition of the ureamolasses feed - block

Table 2 shows the result of the chemical composition of the various feed - block. The UMFB D had the highest $(\mathrm{p}<0.05)$ DM content. The DM contents of the various UMFB ranged from 88.33 to $91.16 \%$. Highest but similar values were recorded for the crude protein contents of UMFB B $(21.65 \%)$ and $C(21.70 \%)$. The UMFB D $(18.62 \%)$ had least value of $\mathrm{CP}$ while intermediate value was recorded for UMFB A $(19.58 \%)$. The crude fibre contents ranged from 3.70 to $3.19 \%$ in UMMB B and $A$, respectively and ether extract value from 2.73 (UMFB C) to $2.37 \%$ (UMFB A). The ash content values of $2.34 \%$ (UMFB B) and $2.22 \%$ (UMFB C) were noted. Result of fibre fraction revealed that UMFB A contained $34.6 \% \mathrm{NDF}, 15.5 \% \mathrm{ADF}$ and $14.6 \%$ ADL while similar values of ADF and ADL were recorded for UMFB B $(16.7 \%$ and $15.3 \%)$ and $\mathrm{D}(16.8 \% 15.50 \%)$, respectively.

Table 2: Proximate composition (g/100gDM) of urea-molasses feed-blocks.

\begin{tabular}{|c|c|c|c|c|c|}
\hline \multirow[t]{2}{*}{ Parameters } & \multicolumn{4}{|c|}{ Feed-block Treatm ents } & \multirow[t]{2}{*}{ SEM } \\
\hline & $\mathrm{A}$ & $\mathrm{B}$ & $\mathrm{C}$ & $\mathrm{D}$ & \\
\hline Dry matter & $89.33^{\mathrm{c}}$ & $88.33^{\mathrm{d}}$ & $90.52^{b}$ & $91.16^{\mathrm{a}}$ & 0.41 \\
\hline Crude protein & $19.58^{\mathrm{b}}$ & $21.65^{\mathrm{a}}$ & $21.70^{\mathrm{a}}$ & $18.62^{\mathrm{c}}$ & 0.50 \\
\hline Crude fibre & $31.9^{\mathrm{c}}$ & $37.0^{\mathrm{a}}$ & $35.0^{\mathrm{b}}$ & $35.0^{\mathrm{b}}$ & 0.70 \\
\hline Ether extract & $2.37^{\mathrm{b}}$ & $2.40^{\mathrm{b}}$ & $2.73^{\mathrm{a}}$ & $2.70^{\mathrm{a}}$ & 0.06 \\
\hline Ash & $2.30^{\mathrm{a}}$ & $2.34^{\mathrm{a}}$ & $2.22^{\mathrm{b}}$ & $2.31^{\mathrm{a}}$ & 0.02 \\
\hline
\end{tabular}


In vitro fermentation of urea-molasses feed - blocks m ade with different bind ers for ru mina nts

Table 3: Fibre Composition (g/100gDM) of u rea-molasses feed-blocks.

\begin{tabular}{llllll}
\hline Parameters & \multicolumn{2}{l}{ Feed-block Treatments } & SEM \\
\cline { 2 - 5 } & $\mathrm{A}$ & $\mathrm{B}$ & $\mathrm{C}$ & $\mathrm{D}$ & \\
\hline NDF & $34.6^{\mathrm{a}}$ & $34.1^{\mathrm{b}}$ & $34.1^{\mathrm{b}}$ & $32.1^{\mathrm{c}}$ & 0.36 \\
ADF & $15.5^{\mathrm{b}}$ & $16.7^{\mathrm{a}}$ & $15.5^{\mathrm{b}}$ & $16.8^{\mathrm{a}}$ & 0.24 \\
ADL & $14.6^{\mathrm{b}}$ & $15.3^{\mathrm{a}}$ & $11.5^{\mathrm{c}}$ & $15.5^{\mathrm{a}}$ & 0.61 \\
\hline
\end{tabular}

${ }^{a, b, c}$ Mean values in the same row with different superscripts differ significantly $(\mathrm{P}<0.05)$, SEM Standard Error of Mean, NDF - Neutral Detergent Fibre, ADF - Acid Detergent Fibre, ADL - Acid Detergent lignin. UMFB A (Cement only), UMFB B (cement + clay), UMFB C (cement + cassava starch), and UMFB D (cassava starch + clay).

\section{Concentration of methane, $\mathrm{NH}_{3}-\mathrm{N}$ and pH of urea-molasses feed - block.}

In Table 3, UMFB B had the highest ( $\mathrm{p}<$ $0.05)$ acetic, oleic and lactic acid productions $(48.00,11.13$ and $36.00 \%$, respectively), while similar values ( $\mathrm{p}>0.05)$ of oleic and lactic acids were recorded for UMFB C (11.3 and 36.5\%) and D (11.3 and $0.0364)$ respectively. The UMFB A had the least propionic acid (19.50\%). UMFB B had highest butyric acid concentration $(20.2 \%)$ and highest ratio of acetic and propionic acids (1.89). The value of methane production ranged from 13.50 in UMFB A to $17.00 \mathrm{ml} / 200 \mathrm{mgDM}$ in UMFB B. Low $\mathrm{pH}(\mathrm{p}>0.05)$ was recorded for all the UMFB. The $\mathrm{pH}$ values ranged from 5.8 to 6.3. Concentration of $\mathrm{NH}_{3}-\mathrm{N}$ and methane production observed in this study were significant $(\mathrm{p}<0.05)$ with UMFB B having the highest values of $\mathrm{NH}_{3}-\mathrm{N}(6.1$ $\left.\mathrm{mgdL}^{-1}\right)$ and methane $(17.00$
ml/200mgDM) while UMFB A had least values of $\mathrm{NH}_{3}-\mathrm{N}$ (4.6 mgdL ${ }^{-1}$ ) methane (13.50 ml/200mgDM).

\section{Discussion}

Chemical composition of the ureamolasses feed - block

Fertilizer grade - urea was used to prepare the multi nutrient feed - blocks for the supply of non-protein nitrogen for rumen microbes while molasses supplied readily fermentable carbohydrate for energy. The crude protein obtained in this study was lower than the report of Wanapat and Khampa (2006), who reported lower NDF but higher ADF values. However, higher NDF values were reported by Boukila et al. (2006). This might be because higher quantity of coarse rice bran and lower quantity of urea was used in their study. Comparable results of ether extract, ash and crude fibre were reported by Onwuka (1999). The reason for the high DM content of UMFB C and D containing cassava

Table 4: Volatile fatty acid production of urea-molasses feed-blocks.

\begin{tabular}{llllll}
\hline Parameters (\%) & \multicolumn{2}{l}{ Feed-block Treatments } & SEM \\
\cline { 2 - 5 } & A & B & C & D & \\
\hline Propionic acid & $19.50^{\mathrm{c}}$ & $25.50^{\mathrm{b}}$ & $24.50^{\mathrm{b}}$ & $30.50^{\mathrm{a}}$ & 0.15 \\
Acetic acid & $18.00^{\mathrm{c}}$ & $48.00^{\mathrm{a}}$ & $24.00^{\mathrm{b}}$ & $23.00^{\mathrm{b}}$ & 0.44 \\
Oleic acid & $8.50^{\mathrm{b}}$ & $11.30^{\mathrm{a}}$ & $11.30^{\mathrm{a}}$ & $11.30^{\mathrm{a}}$ & 0.45 \\
Lactic acid & $27.00^{\mathrm{b}}$ & $36.00^{\mathrm{a}}$ & $36.00^{\mathrm{a}}$ & $36.50^{\mathrm{a}}$ & 0.15 \\
Butyric acid & $15.80^{\mathrm{c}}$ & $20.20^{\mathrm{a}}$ & $19.60^{\mathrm{b}}$ & $19.50^{\mathrm{b}}$ & 0.66 \\
Acetic: Propionic & $0.78^{\mathrm{c}}$ & $1.89^{\mathrm{a}}$ & $0.98^{\mathrm{b}}$ & $0.75^{\mathrm{c}}$ & 0.18 \\
\hline
\end{tabular}

${ }^{a, b, c}$ Mean values in the same row with different superscripts differ si gni ficantly $(\mathrm{P}<0.05)$, SEM Standard Error of Mean. UMFB A (Cement only), UMFB B (cement + clay), UMFB C (cement + cassava starch), and UMFB D (cassava starch + clay). 
Table 5: Concentration of methan e, $\mathrm{NH}_{3}-\mathrm{N}$ and $\mathrm{pH}$ in urea-molasses feed-blocks.

\begin{tabular}{llllll}
\hline Parameters & \multicolumn{4}{c}{ Feed-block } & SEM \\
\cline { 2 - 5 } & A & B & C & D \\
\hline Methane(ml/200mgDM) & $13.50^{\mathrm{c}}$ & $17.00^{\mathrm{a}}$ & $14.00^{\mathrm{c}}$ & $16.00^{\mathrm{b}}$ & 0.30 \\
$\mathbf{N H}_{3}-\mathrm{N}\left(\mathrm{mgdL}^{-1}\right)$ & $4.60^{\mathrm{d}}$ & $6.10^{\mathrm{a}}$ & $4.80^{\mathrm{c}}$ & $5.10^{\mathrm{b}}$ & 0.20 \\
$\mathbf{p H}$ & 5.80 & 5.86 & 6.30 & 5.90 & 0.12 \\
\hline a,b,c Mean values in the same row with different superscripts differ significantly $(\mathrm{P}<0.05)$, SEM - \\
Standard Error of Mean \\
NH3-N = ammonia nitrogen. UMFB A (Cement only), UMFB B (cement + clay), UMFB C (cement \\
+ cassava starch), and UMFB D (cassava starch + clay)
\end{tabular}

starch as binder might probably be as a result of the fact that cassava starch might not be able to confer high water retention ability on the final mixture of the feed block mixtures when compared with cement and clay binders (Mahir, et al., 2009). The significantly high value observed in CP content of UMFB A could not be explained because cement is not a protein feedstuff. It might be that the cement inclusion triggered proliferation of micro-organisms, leading to the rise in protein. However, the $\mathrm{CP}$ content of the various UMFBs was higher than the 7\% minimum $\mathrm{CP}$ requirement recommended for ruminants in the tropics (Minson, 1980). Feed-block $\mathrm{C}$ having $0 \%$ clay, $5 \%$ cassava starch and $5 \%$ cement in its component had the least ash content.

\section{Concentration of methane, $\mathrm{NH}_{3}-\mathrm{N}$ and pH of urea-molasses feed-blocks.}

The insignificant result observed in methane production might be due to the fact that the same quantity of urea and molasses were supplied to meet microbial need in the

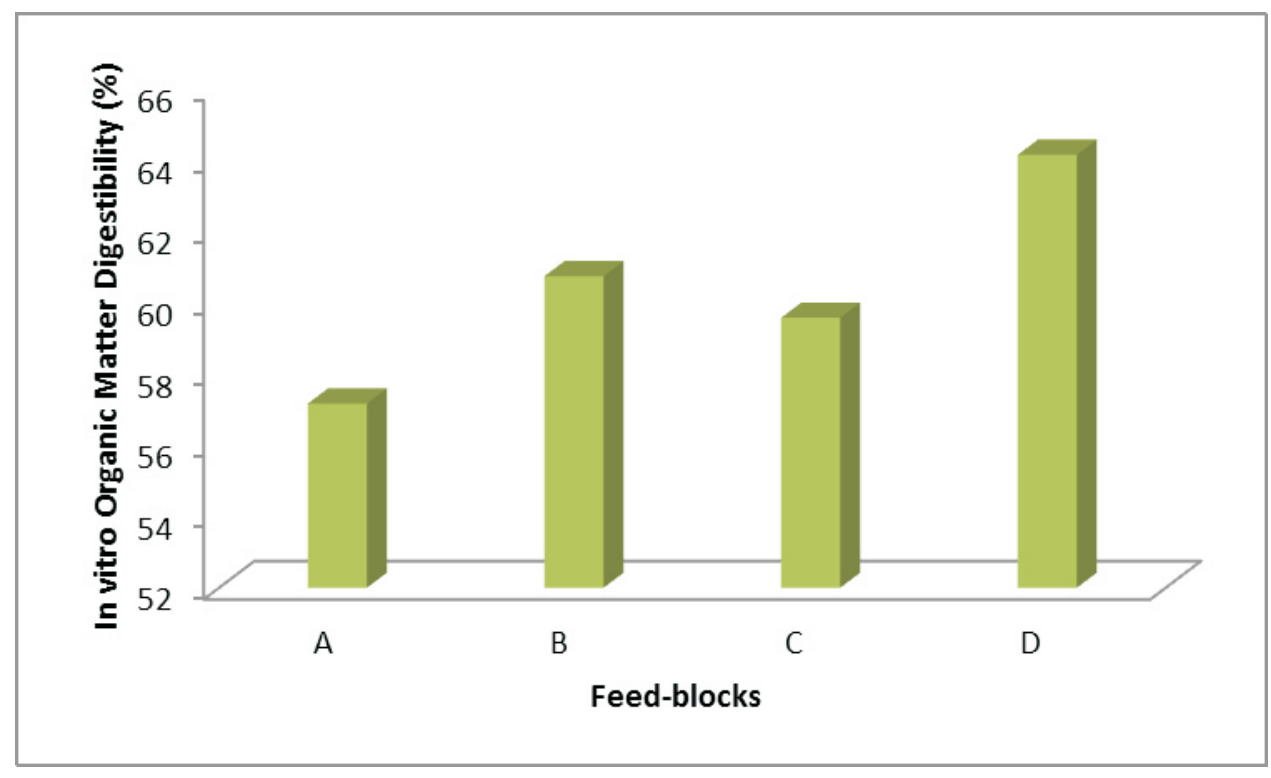

Figure1: In vitro organic matter digestibility (\%) 
rumen. Urea is a non-protein nitrogen source which plays active role in supplying ammonia to rumen microbes for feed degradation which results in microbial protein and methane formation. The result of methane production in the present study was however higher than the report of Isah (2011) when some tropical grasses were degraded in vitro. The high IVOMD result recorded for UMFB D without cement as binder might be as a result of the binding effect of cement on the component of other UMFB containing cement in the other treatments, which might lead to slow release of nutrients for thorough degradation of the organic matter component of the feed. However, when cement was absent in UMFB D, other feed ingredients were not closely bound together to prevent their release for microbial degradation. Also, rapidly fermentable carbohydrates yielded relatively higher propionate as compared to acetate (Makkar, 2000) was the case in UMFB D which had highest propionic acid concentration. UMFB B with cement and clay as binders yeilded highest concentration of the various volatile fatty acids determined except propionic acid while UMFB A with only cement as binder yeilded least quantity of volatile fatty acids. This indicates that combining cement with other binders such as clay and cassava starch could be more effective because microbes use ammonia and energy more effectively if they are released gradually to maintain stable rumen $\mathrm{pH}$ for optimum microbial actvity. However, UMFB A had least methane production. The $\mathrm{pH}$ results $(\mathrm{p}>0.05)$ observed in this study is lower than that reported by Foiklang et al. (2001) for rumen fermentation of swamp buffalo. However, the $\mathrm{pH}$ values are above 5.5 which cause depression to protozoa population in the rumen due to acid intolerance. NH3-N concentration recorded in the present study was higher than the report of Molina et al. (2009), but lower than the observation of Thu, (2001) and Koakhunthod et al. (2001). This might be due to variation in the formulation of the feed-blocks.

\section{Conclusion}

The study showed that the various feed blocks can serve as a dependable supplement which may improve rumen fermentation efficiency during dry season and period of scarcity for ruminants and are therefore recommended as feed-blocks for ruminants on a low-quality forages. Supplementation with UMFB can improve the utilization of low quality roughages by satisfying the requirement of the rumen micro-organisms, by creating better fermentation of fibrous material and increasing production of microbial protein and volatile fatty acids. UMFB B having cement and clay as binders yeilded highest concentration of of the various volatile fatty acids determined except propionic acid while UMFB A with only cement as binder yeilded least quantity of Volatile fatty acids. However, UMFB A had least methane production. It is recommended that the various UMFB be fed to animal to assess their performance.

\section{References}

AOAC (1990) The official Methods of Analysis. $15^{\text {th }}$ edition, Washington DC.

Babayemi, O. J., Demeyer, D. and Fievez, V. 2004. In vitro rumen fermentation of tropical browse seeds in relation to their content of secondary metabolites. Journal of Animal Feed Science 13, Supplementary 1,31-34.

Babayemi, O.J. and Bamikole, M.A. 2009. Nutrient value and In vitro Gas Production of African wild cocoyam 
(Colocasia esculentum). African journal of Food, Agriculture, Nutrtion and Development. 9: (1) 593-607.

Blummel, M and Orskov, E.R. 1993. Comparison of in vitro gas production and nylon bag degradability of roughages in predicting feed intake in cattle. Anim. Feed Sci. Technol., 40: 109-119.

Blümmel, M., Steingass, H. and Becker, K., 1997. The relationship between in vitro gas production, in vitro microbial biomass yield and $15 \mathrm{~N}$ incorporation and its implications for the prediction of voluntary feed intake of roughages. British Journal of Nutrition 77, 911-921.

Boukila, B., Pamo, T. E., Fonteh, F. A., Doumbia, F., Tendokeng, F., Kana, J.R., Mboko, A. V. and Mbenga, L. N. 2006. Formulating Multinutrient Feed - blocks Towards Improving Production and Reproduction in Djallonke sheep. Bulletin Animal Health Production Africa, 54: 152 155

Brar, P.S., Nanda, A.S. and Juyal, P.D. 2006. Reproductive Performance Of Dairy Buffalo Receiving Supplements Of Urea-Molasses Multi-Nutrient Block (UMFB). Animal Production and Health Section, Joint FAO/IAEA Division of Nuclear Techniques in Food and Agriculture, International Atomic Energy Agency, Vienna. Pp 39 50

Chaney, A.L. and Marbach, E.P. 1962. Modified reagents for determination of urea and ammonia. Clinical Chemistry, 8: 130-132.

Duncan, D. G. 1955. Multiple range and multiple F-tests. Biometrics, 11: 1 - 42.

Fievez V, Babayemi $O$ J and Demeyer D 2005. Estimation of direct and indirect gas production in syringes: a tool to estimate short chain fatty acid production requiring minimum laboratory facilities. Animal feed Science and Technology 123 - 124: 197-210.

Foiklang, S. Wanapat, M. and Toburan, W. 2010 Effect of Various Plant Protein Sources in High-quality Feed block on Dry Matter Intake, Digestibility and Rumen Fermentation in Swamp Buffalo. Journal of Animal and Veterinary Advances. 9 20:25932599 D O I : 10.3923/javaa.2010.2593.2599

Isah, O.A. 2001. In vitro gas production of some tropical grasses using inocula from cattle, sheep and goats. Book of abstract "Tropentag, 2011 ", Development on the margin. International research on food security, natural resources management and rural development. October $5^{\text {th }}-6^{\text {th }}$, 2011. University of Bon. Germany. Pp385.

Koakhunthod S, Wanapat M, Wachirapakorn C, Nontaso $\mathbf{N}$, Rowlinson $\mathbf{P}$ and Sornsungnern $\mathbf{N}$. 2001 Effect of cassava hay and high quality feed - block supplementation on milk production in lactating dairy cows. In: Proceedings of International Workshop on Current research and development of cassava as animal feeds, organized by Khon Kaen University and Swedish International Development Agency (SIDA) and Swedish Agency for Research and Cooperation with Developing Countries (SAREC), July 23-24, Kosa Hotel, Thailand.

Mahir D, Bjorn, B, and Andrew, J. B. 2009. Research Letters in Materials Science Volume, 2009, Article ID $854701, \quad 3 \quad \mathrm{p} \mathrm{a} \mathrm{g}$ e s 
doi:10.1155/2009/854701

Makkar, H. P. S. 2000. Application of the in vitro gas method in the evaluation of feed resources, and enhancement of nutritional value of tannin-rich tree leaves and agro-industrial by product. In: Development and field evaluation of animal feed supplemental packages. Proceeding of final review meeting of IAEA Technical cooperation Regional AFRA Project organised by Join FAO/IAEA Division of Nuclear Technique in Food and Agriculture held in Cairo Egypt,25-29 Nov 2000 .pp $23-40$ http://wwwnaweb.iaea.org/nafa/aph/public/iaeatecdoc-1294.pdf

Makkar, H.P.S. 2006. Improving Animal Productivity Through Meeting Nutrient Deficiencies with MultiNutrient Blocks, Enhancing Utilization Efficiency of Alternate Feed Resources, and Controlling Internal Parasites: A Summary. Animal Production and Health Section, Joint FAO/IAEA Division of Nuclear Techniques in Food and Agriculture, International Atomic Energy Agency, Vienna. Pp 1 - 9

Menke, K. H. and Steingas H. 1988 Estimation of energetic feed value from chemical analysis and in vitro gas production using rumen fluid. Animal Research and development 28:7-55

Minson, J.D. 1980 Nutritional differences between tropical and temperate pastures. In: F.H.W. Morley (Editor), Grazing Animals. C.A.B., Furnham Royal, Slough, UK. Pp. 167-182

Molina-Alcaide, E., Pascual, M. R., Cantalapiedra-Hijar, G., MoralesGarcía, E. Y. and Martín-García, A. I. 2009 Effects of concentrate replacement by feed blocks on ruminal fermentation and microbial growth in goats and single-flow continuousculture fermenters. Journal of Animal Science 87:1321-1333.

Onwuka, C.F.I. 1999. Molasses block as supplementary feed resource for ruminants. Arch. Zootec. 48: 89-9 4.

Samuel, M., Sagarthewan, S. Thomas, J. and. Mathen, G., 1997. An HPLC method for estimation of volatile fatty acids of ruminal fluid. Indian Journal of Animal Science 69: 805-807.

SAS \{Statistical Analysis System\}. 1990. SAS/STAT User's guide, version 6 (Volume 2; Fourth Edition). Cary North Carolina, SAS Institute, Incorporated 846p.

Thu, N. V. 2001. Effect of urea-molassesmineral supplementation on in vivo, in situ and in vitro feed digestibility of swamp buffaloes. Proceedings of Buffalo workshop December, 2001. $\mathrm{T} \quad \mathrm{h} \quad \mathrm{a} \quad \mathrm{i} \quad \mathrm{l}$ a $\mathrm{n} \quad \mathrm{d}$ http://www.mekarn.org/procbuf/thu.ht $\underline{m}$

Tilley J M A and Terry R A. 1963. A twostage technique for the in vitro digestion of forage crops. Journal of British Grassland Society 18:104-11.

Van Soest, P. J., Robertson and Lewis, B. A. 1991. Methods for analysing dietary fibre and Nonstarch polysaccharides in relation to animal nutrition. Journal of Dairy Science 74: 3583-3597.

Wanapat, M. and Khampa, S. 2006. Effect of Cassava Hay in High-quality Feed - block as Anthelmintics in Steers Grazing on Ruzi Grass. Asian-Aust. Journal of Animal Science 2006. 19, No. 5 : 695-698

Received: 3nd July, 2011 Accepted: 29th April, 2012 